\title{
Information commons at Brigham Young University: Past, present, and future
}

\author{
Michael J. Whitchurch \\ michael_whitchurch@byu.edu \\ Jeffrey C. Belliston \\ jeffrey_belliston@byu.edu \\ William Baer
}

Follow this and additional works at: https://scholarsarchive.byu.edu/facpub

Part of the Library and Information Science Commons

Original Publication Citation

Reference Services Review, Vol. 34 No. 2, 26, 261-278.

\section{BYU ScholarsArchive Citation}

Whitchurch, Michael J.; Belliston, Jeffrey C.; and Baer, William, "Information commons at Brigham Young University: Past, present, and future" (2006). Faculty Publications. 965.

https://scholarsarchive.byu.edu/facpub/965 


\section{Information commons at Brigham Young University:}

past, present, and future

\section{Introduction}

What is an information commons? The word "commons" is defined, according to Webster's II New College Dictionary, as "a section of land belonging to or used by a community as a whole (Webster's II New College Dictionary,1995, p.226)”. Cowgill et al. defined an information commons as "a specific location designated to deliver electronic resources for research and production that is maintained by technically proficient staff (Cowgill et al., 2001, p. 432).” Not only is technically proficient staff needed but research proficient staff as well. In other words, an information commons is a centralized location where the common activity is to find, use and create information. It is a place where research, group collaboration and consultation can all be done with the help of appropriate technologies in support of the patrons. In an academic setting it provides the ability to see a project-individual or group-from inception to completion.

Examples of information commons can be found at many colleges and universities, including the University of Arizona, the University of Southern California, Emory University, the University of Minnesota, and Brigham Young University (2005). The information commons concept has not been widely implemented in the corporate world but at least one example is the Commons at the National Institute of Standards and Technology Library (Allmang et al., 2006). Although the mission, definition and makeup of each information commons may vary, the idea of combining several desired services and resources in one location remains consistent. In this technological age, "libraries not only have to provide the technology necessary for patrons to use their OPACs, but also must supply a means for access to scholarly digital resources and a growing number of electronic databases” (MacWhinnie, 2003, p. 241). Additionally, resources to create or complete an end product need to be available, as well as staff to support the hardware and software. To this end the technology and services staff needs to be trained adequately to provide assistance.

The Lee Library at Brigham Young University (BYU) has attempted to implement the services and resources patrons need to succeed during their academic sojourn, and later, their professional career. BYU’s experience has generated interest as evidenced by citations to the document produced by the investigation team[1]. This paper goes beyond the investigation to the actual process of creating and supporting the information commons through the first 18 months of operation.

\section{Idea, investigation, proposal and implementation}

\section{Idea}

At the beginning of the 2002-2003 academic year the Deputy University Librarian was appointed as University Librarian for the Harold B. Lee Library. From the start he was focused on providing the best service to students. As a result he attended BYU Student 
Advisory Council meetings and asked what students wanted and needed from the Library. The Faculty Library Council was reinvigorated and questioned about how the Library could better promote student learning. Further clarification of the changing needs of higher education students was gained by participation in the meetings of several organizations to which the Lee Library belongs, including the Utah Academic Library Consortium (UALC), the Greater Western Library Alliance (GWLA), the Consortium of Church and Library Archives (CCLA), and the Association of Research Libraries (ARL).

All of these activities and interactions convinced the University Librarian that student collaboration, assisted by technology, had become increasingly important to student learning. With this in mind, the University Librarian drove the investigation and implementation of BYU's information commons.

When the authors were undergraduates regular participation in collaborative projects was unusual. An occasional study group for an upcoming exam constituted the bulk of any group work outside of class. The environment has certainly changed. James Michael Kusack described the change well. "The solitary worker immersed in a very personal life of the mind is no longer the only kind of researcher seen in the library. Teachers in secondary schools, undergraduate programs, and graduate schools regularly ask students to prepare group projects, papers, and exercises. These assignments stem from the recognition that a higher quality of learning can result and the perception that this is the way the real world works and students must develop group skills if they are to be successful after graduation” (Kusack, 2002, p. 79). Kusack also noted that libraries can respond to this change in the areas of facilities, software, and "staffing, policy, and attitude” (p.81). Nearly every implementation of the Information Commons concept familiar to the authors, including the implementation in the Lee Library at Brigham Young University, addresses all three of these areas.

\section{Investigation and proposal}

In the initial stages of planning the Information Commons, the Harold B. Lee Library organized the Information Commons Project Team to investigate successful Information Commons. In addition, this team was to determine the best model for Brigham Young University to use in implementing its own Information Commons. The Information Commons Project Team in the Lee Library began its investigation in mid-February 2003 and was given less than two months to report to the Library's Administrative Council.

Throughout the process, efforts were made to include non-library viewpoints. In addition to librarians, the team included representatives from the Faculty Advisory Council (BYU's faculty senate), the Office of Information Technology (OIT), the Center for Instructional Design, and the university's Student Advisory Council (SAC). Feedback was also sought from the entire SAC membership and various other members of the faculty. The team performed an environmental scan of best practices for information commons through scouring the literature and searching the internet. Team representatives also visited the University of Arizona, the University of Southern California (USC), the California Institute of Technology, the University of California at Los Angeles (UCLA), 
the Georgia Institute of Technology, Emory University, the University of Tennessee at Knoxville (UTK), and the University of North Carolina at Charlotte (UNCC). The team was instructed to include in its report "A recommendation outlining the course of action the Lee Library should take with regard to an information commons ... [including] goals and intent; an identification of services, proposed location(s), impact on existing services; necessary resources, and plan of operation” (Harold B. Lee Library 2003a).

The team was charged to recommend "various services, resources, and facilities that would be appropriate and necessary for the Lee Library to operate and sustain a state-ofthe-art information commons" (Harold B. Lee Library 2003a). The investigative process gave the team a feel for the best practices of other universities, however, determining what constituted a state-of-the-art information commons was difficult to capture until components were identified.

The Team's final report gave three different recommendations to be implemented depending upon the level of financing received from the institution. The three different options proposed were:

1) Upgrade to a Commons Proposal.

2) State-of-the-Art Commons Proposal.

3) Blue Sky Proposal. Only the Blue Sky Proposal included all seven components described below.

The Administrative Council decided that the Commons implemented would be between the "State-of-the-art" and the "Blue Sky" proposals and that it would be implemented "in a phased approach over a three to five year period" (Harold B. Lee Library 2003b).

The team identified the following seven components of0 Information Commons:

(1) Reference and student workstations.

(2) Collaborative learning rooms and areas.

(3) Electronic classrooms.

(4) Multimedia workstations.

(5) Consultation stations.

(6) Writing lab.

(7) Lounge area.

Although no two information commons studied were the same, the best had many (if not all) of these components. These components were then analyzed in light of the Lee Library's values and mission statement (Harold B. Lee Library, 2001) as well as the broader goals of BYU as detailed in The Aims of a BYU Education (Brigham Young University) to determine which configuration would best serve the needs of BYU's students.

Reference and student workstations. The most basic component of an information commons is that it integrates traditional library reference service with computer workstations that include a variety of productivity software. If not done well, the result is nothing more than a computer lab surrounding a reference desk. However, if done 
correctly, the result is far from traditional. The key to success is service. Students should receive help with traditional reference questions as well as technical questions regarding software on the workstations. Some libraries have attempted to do this by staffing the desk with both reference specialists and lab technicians. This model has had some success at schools like Georgia Tech, but the model used at USC's Leavey Library (Crockett et al., 2002) and at the University of Arizona's Information Commons seems to work better. At these libraries, all reference employees must have at least basic competency in the most popular software programs in addition to their reference skills. The main obstacle to effective integration seems to be getting "buy-in" from less technically savvy library faculty. Once these librarians are committed to making integrated reference succeed, they are willing to put forth the effort to learn the needed technical skills.

In addition to services, the physical placement of the computer workstations is also important. Collaboration among students is increasing. As Lizabeth Wilson pointed out in an ARL Bimonthly Report, “Active learning and group work are preferred over passive modalities and the solitary learner. Students are working in groups as they search for mutual understanding and create new knowledge. Collaborative learning requires collaborative space” (Wilson 2002). More and more often, multiple students want to work together at the same workstation. Almost every site visited stressed the need to accommodate student collaboration. Single-person computer desks are too confining. Long, flat surfaces with computers spread apart give space for two to three students to work together. Several libraries visited by the team had pods of computers scattered about the commons to enable more effective collaboration. Extra seating should be stationed around pods and by other workstation. Chairs or stools with wheels seem to be preferred by students because they can be moved around more easily.

The size and configuration of both the print reference collection and the reference desk may also need to be altered to make room for more spacious computer workstation areas and to facilitate more librarian-student interaction. Georgia Tech library staff is moving rarely used print indexes that have been duplicated by electronic resources to the stacks to make additional room for the next phase of its information commons. They will spread the remaining print reference collection around the new section of the information commons to further remind students of the integrated aspect of learning in the Commons.

The service model of an information commons involves more librarian-student interaction with a computer. Consequently, the design of the desk should be revisited to facilitate such interaction. The traditional monolithic desk with a librarian behind it and a patron on the other side needs to give way to a desk cut up into smaller, less imposing pieces thereby making it easier to invite students behind the desk to receive side-by-side help.

Collaborative learning spaces. To re-emphasize, collaboration among students is increasing as the concepts of team building and team research become more prevalent in higher education. "[Students] will be better served by an integrative, dynamic model that contextualizes information and that creates collaborative workspaces where group 
process can shape knowledge in ways that parallel the large-scale evolution of knowledge in the culture around us" (Beagle, 1999). For many years group study rooms have been used to address this need. When the new addition to the Lee Library opened in November 2000 , it included several new study rooms. The demand for these rooms continues to increase.

Almost every library visited by the team stressed the importance of collaborative-learning rooms. These are essentially group study rooms equipped with technology. By adding a workstation to a group study room the students can collaborate on papers or practice group presentations without disturbing other patrons. In addition to workstations, some include an electronic whiteboard, a projector, and additional laptop drops. Technical and reference support for the collaborative-learning rooms should be available from the information commons desk. In order to facilitate the integration of technological and traditional library services it was strongly suggested that at least one wall of each of these rooms includes large windows. This adds to the feeling of being a part of the information commons, and also alleviates additional security concerns caused by having expensive equipment in isolated areas.

In addition to collaborative learning rooms, some information commons have comfortable collaborative learning areas. These areas are like group study rooms without walls and tables. Unlike traditional study areas with tables, collaborative learning areas are designed to encourage collaboration among students and facilitate the use of technology. These vary greatly in size and accommodations. Some provide only comfortable seating combined with ports for laptops. Others provide a computer and projector to allow students to practice presentations. Collaborative learning areas tend to foster a less rigid atmosphere. One area of concern with collaborative learning areas is the noise, so care should be taken when placing these areas.

Electronic classrooms. Many universities assume that students come complete high school with a working knowledge of basic production software such as Word, Excel, and PowerPoint. Often this assumption is incorrect. Some information commons have added at least one electronic classroom to train students in basic technical skills as well as information retrieval skills. The University of Arizona offers "Home Depot"-style classes, advertising the subjects for classes and inviting anyone to attend. Georgia Tech offers periodic "open-forum" classes where the students come to ask for training on any number of topics. Teaching faculty can book the classrooms in UCLA's information commons for their classes to use. At the end of the semester, when training needs are lower but workstation demands are greater, Arizona opens up the computers in its electronic classrooms as additional student workstations.

Electronic classrooms tend to be one of two flavors. The first, and most popular, is to have individual workstations for hands-on learning. Workstations should be configured with all of the software available on information commons machines with the possible exception of high-end multimedia software. UNCC has a portable wireless classroom with 20 wireless laptops and a portable hub that can turn any classroom into a hands-on 
electronic classroom. The second flavor of classroom is configured so that a control console can display visuals from a computer, video, or DVD.

Multimedia workstations. Although not a critical component of an information commons, multimedia workstations provide students with additional tools to integrate information, technology, and learning. As multimedia technology becomes more prevalent and easier to use, the ability to create and manipulate multimedia is becoming more desirable. Multimedia workstations and consultants to teach multimedia skills can be a great boon to students. Most of the information commons visited had some form of media-creation component.

One of the best examples of multimedia workstations visited by the team was "The Studio” at UTK (Dewey, 2002). The Studio employs two full-time employees (one faculty and one staff) and 3.5 FTE student consultants. It has high-end multimedia stations with the hardware and software to create all types of multimedia products. These stations are equipped with scanners, digital and analog video inputs and outputs, and several versions of editing software. Additional "basic" multimedia stations included software and scanners. Digital video cameras, digital cameras, tripods and other equipment are available for check-out. Students can reserve the high-end stations -as well as schedule consultants to help with projects. Many students come to trust their consultants so much that they schedule facilities only when certain consultants are available.

Both Georgia Tech and UTK mentioned that the best feature of the multimedia area is the one-on-one assistance to help students and faculty with their projects. This service enables students to develop skills while drawing on the expertise of others. The schedules of consultants are advertised, and often pair new projects with a consultant whose specialty is creating that type of media. The value of providing knowledgeable assistants for multimedia creation should not be underestimated. Other institutions had not adequately budgeted for technical consultants, and as a result their workstations were underutilized.

Consultation stations. Consultation stations are computers reserved for more in-depth, one-on-one research assistance and training. In the digital environment it is very important to integrate reference and library instruction to offer "information seekers the most convenient and supportive learning environment” (Rader, 1999, p. 219). Located near the desk, consultation stations provide a less hurried atmosphere to teach information-finding or program-usage skills. If a reference interview uncovers a need for in-depth research assistance or personal instruction, the librarian can easily move to the consultation station to avoid further distractions.

Consultation stations also provide an opportunity to bring the teaching community into the library. Georgia Tech allows teaching assistants (TAs) to schedule consultation stations to provide one-on-one assistance to their classes in the information commons. Students can go directly to the consultation stations during the TAs "office hours" and, after working with the TA, can conveniently stay in the information commons to work on 
their projects. In a similar manner, subject librarians could schedule consultation stations to help individual students in a class with a specific assignment.

Writing lab. Having a writing lab in the information commons is a matter of convenience for students. It provides help with research papers when and where the students are writing their papers. Each of the information commons that provide writing labs does so in conjunction with other entities on campus. USC and Arizona mentioned that their labs are heavily used. Regular hours should be scheduled, with the possibility of extended hours at busy times of each semester.

Lounge area. Almost every information commons visited includes some type of computer-free lounge area. These areas are filled with comfortable chairs, which are perfect for taking a break from study. Arizona has leather chairs and couches and a large TV in its information commons lounge. For the most part, the lounge areas are quiet zones. Lounge areas are inviting and diminish the computer lab feel of the information commons.

\section{Implementation}

All of the above components were considered for the implementation of the information commons in the Lee Library at BYU. For a comparison table of components of the General Reference section of the Lee Library before and after implementation of the information commons, please see the Appendix.

The information commons was implemented in what was the General Reference area of the library. This area is located near the entrance to the library and is the first stop for many who enter the library.

The most important aspect of the information commons is the space provided for group collaboration. To this end collaboration stations, group study rooms, study tables and comfortable lounge chairs that can be arranged in groups were implemented.

Group study rooms. Enhancing the group study rooms with technology involved Library Information Systems (LIS) personnel; the Building Manager; A/V experts and networking personnel from the OIT; carpenters, electricians, painters, and carpet installers from Physical Facilities; representatives from Polyvision; and student Multimedia Consultants and the Web Designer from General Information Services. The project required planning; demolishing the existing wall dividing the two rooms; rebuilding and painting a wall two inches thicker than the original; providing power and data for the multimedia whiteboard, printer, and laptops; repairing carpet damaged in the construction and electrical and data work; installing and programming the ceiling mounted projectors; installing the multimedia whiteboard and associated printer; receiving training on the board's operation from Polyvision representativess; training department personnel; preparing training aids for students who would use the room; installing cipher locks on the doors; creating procedures for changing combinations regularly to prevent unauthorized use of the rooms; making relevant information about the rooms and associated links available on the Library's web page; and setting up 
procedures for the scheduling and control of materials (erasers, markers, projector remotes) associated with the rooms.

Study tables, carrels, and individual workstations. Employees supervised by the Building Manager moved the individual study carrels and chairs. They also moved the study tables and chairs - some to a new location within the area and some to other areas of the library or to storage. However, in the case of eight of these tables, OIT personnel disconnected the data wiring and electrical shop personnel disconnected the power before the tables were moved. The tables and carrels were moved to open up space for collaborative workstations and other information commons elements.

For individual workstations, the only change was the addition of scanners and associated software to eight of the existing workstations. LIS personnel ordered these scanners along with other new computer equipment installed in the Information Commons. The addition of software required that the "image" on the scanning workstations be updated. LIS personnel loaded the new image on the workstations and physically installed the scanners.

Collaborative workstations and general reference collection. Collaborative workstations - technology and furniture designed and laid out to support group workform the heart of the information commons. Installing these stations represented the bulk of the effort. In addition to moving study tables and individual carrels to create space for collaborative workstations, the print reference collection also shrunk in size to free up more space for these stations.

The General Reference collection housed many national bibliographies and national library catalogs in addition to reference works not suitable for specialized subject reference collections. The Biography Reference collection, established when little or no good indexing of collected biographical works existed, housed works of collected biographies. Recognizing that excellent indexing of collected biographical works now exists in works such as Biography and Genealogy Master Index and that usage of print national bibliographies and library catalogs has declined dramatically, the Library determined:

- To drastically reduce the size of the General Reference collection by sending the national bibliographies and catalogs to the stacks.

- To disperse the Biography Reference collection to subject reference areas or to stacks as appropriate.

The stacks management section of Access Services moved both the biographical materials and the national bibliographies and library catalogs to their new locations. Fortuitously, the Stacks Manager coordinated the integration of the national bibliographies and library catalogs into the non-reference $\mathrm{Z}$ collection as it was being relocated due to an unrelated building project. Due to the volume of items being moved and to their low usage, these items were moved without being re-lettered or immediately changed in the online catalog. As of this writing some of the items have still not been relettered but the catalog has been updated to reflect the correct location of the materials. 
Despite initial misgivings, this has not been a problem because of low use of most of these materials.

The biographical materials, on the other hand, are used more heavily. Before being sent to their new locations, these materials were re-lettered and their catalog records were updated. Because a large proportion of them were transferred either to the Social Science Reference collection or to the general stacks, shifts of both the Social Science Reference collection and the Social Science stacks collection in the same room were necessary. Stacks Management handled both shifts and required several months to complete them.

The General Reference collection also included many printed general newspaper and periodical indexes stemming from a time when bound periodicals were dispersed throughout the building. Given that the Library brought the periodicals together in a central location in 1999, it seemed reasonable to move the print periodical indexes to that facility and the printed newspaper indexes to the microforms area where the newspapers they index are found on microfilm. Making all of these changes necessitated a thorough review and revision of the collection development policy governing reference collections-a process involving multiple committees and discussions before receiving administrative approval.

\section{Inauguration}

The information commons at Brigham Young University opened February 24, 2004. At opening there were 26 “Collaboration Stations” and two "Creative Learning” rooms for groups. In addition, there were 50 individual workstations. Two Macromedia stations, for web site editing and creation, were also a part of the facility at opening and four high-end multimedia stations came online about one month later.

This area is now known by many as the "No Shhh! Zone" due to a marketing campaign started at inauguration. Whispers are not required and group discussion is encouraged. At the beginning there were some complaints about the noise but they have dwindled to practically nothing. There are many other locations in the library that provide quiet areas for students, the largest of which is just around the corner from the information commons. In fact, students like the ability to use a normal voice while collaborating. Somewhat surprisingly for some personnel, the study carrels and tables that remained in the Commons are still very heavily used for individual study. Apparently, many students like to study in an area that is not quiet, but has the soft hum of activity.

One of the purposes of the information commons was to give patrons what they want. As such a variety of resources, support, and spaces have been provided. But, as with other librarians, BYU's librarians struggle with the age-old question: Is what patrons ask for what they really need? In this vein, BYU has determined that much of what happens in the information commons will be decided by the patrons by what they use most and what they gravitate toward in terms of study space. 


\section{First 18 months of operation}

When the information commons began, the head of General Reference agreed to take the responsibility as another part of his job. This was with the provision that, if the area was successful, an open faculty position would be re-purposed to be the information commons section head. Six months after the Commons opened, a new librarian was hired to fill that position. During the time prior to the hiring of the section head the information commons functioned in a pre-state-of-the-art condition. Some of the upgrades to the current state were in process when the new librarian began work.

As part of the proposed phase process the number of components in the information commons, including equipment and staff, have been increased in size over time. For example, in January 200512 additional collaboration stations were added to the existing group of 26, as well as scanners for most of those stations. More increases are also planned.

Every attempt was made to begin the information commons with what the students wanted. By implementing the information commons in phases, there is time to discover, through use and use patterns, what was and is actually desired. Representatives from SAC requested input from the whole council and relayed their suggestions to the investigation team, many of which were implemented. All indicators pointed to the fact that students wanted and needed more computers for course work. In addition to the many individual computers, services are also provided for a large number of groups. These include consultation services on library research, multimedia project editing and creation, website creation and management, scanning and image creation and manipulation, help with standard productivity and with class specific software (i.e. software requested by faculty members to support course curriculum), and the use and implementation of all of the above in a cohesive project or paper. The goal is not to create projects for students but to teach them the skills necessary to complete the project on their own.

The information commons provides space for the campus Publication Lab where students can go for help on publishing projects or papers. They are helped to prepare the document and to find appropriate outlets for publication. Space has recently been designated for the Writing Fellows to use for consultations with students in classes to which the fellows have been assigned to help those students with their writing. The fellows have been assigned a table in the Commons where this assistance can be given. In addition, they have access to small table-top white boards and the ability to reserve Commons Computers.

\section{Staffing}

Staffing has undergone a major shift since the opening of the information commons. When the Commons opened, the students, faculty and staff who supported the new area were drawn from a variety of locations throughout the library. These individuals provided the combination of diverse backgrounds needed in the information commons. 
Full-time faculty and staff. The group of full-time faculty and staff for the information commons was kept when the General Reference area was converted to the information commons. There were two faculty librarians and the previously mentioned open faculty position, one information specialist with an information content focus and a department assistant. The department assistant was changed to be a multimedia student manager and a full-time position was re-purposed from elsewhere in the library to become an information specialist with an information technology focus. Six months after opening the section head was added to the group with the filling of the open faculty slot.

Students. The students who support the information commons were drawn from three different locations: LIS, Library Instruction, and General Reference. Through improved training and re-thinking traditional ways of staffing, service has been enhanced as the number of student reference assistants has been reduced while, at the same time, the number supporting the computers and multimedia stations has increased.

The students who came from Library Instruction had been supporting the bibliographic instruction sessions as computer TAs, assisting the librarians who were teaching the sessions. At the time of opening, these students still supported the instruction sessions, as well as providing service at the General Reference and Information desks. This created an issue of having too many students during slow instruction periods and too few students during times of heavy instruction demands. Beginning in January 2005 a decision was made to hire on-call TA's to support the instruction sessions, allowing the reference desk students to focus their work in the Commons. These students are, however, still trained and available to TA in instruction sessions during the heaviest teaching times.

The students assisting with computer questions in the information commons were drawn from LIS and had more knowledge of technology, especially of computer software. In January 2005 this group of students was also assigned to provide regular support to the satellite commons located in the periodicals section of the Library. The students who originally provided multimedia support were those who had supported the equipment of the Library's auditorium and produced videos when requested by the Library administration. They retained these responsibilities at the same time as they assumed responsibility to provide multimedia consultation and support in the Commons. After the first year of operation, it became logical to split the multimedia group into two entities; one, attached to the Library's Learning Resource Center, dealing with the auditorium support and video production and one dealing with patron support of multimedia questions in the information commons. When this split took place in May 2005, it was thought that there would still be separate groups of students to answer general computer questions and to provide multimedia consultation. However, the computer assistants and multimedia consultants were subsequently merged into one group that answers both computer questions and provides multimedia consultation.

\section{Hiring and Training}

The most important characteristics of students hired in the information commons, are a good customer service attitude, adaptability to change, and a continuous desire to learn new skills. Of secondary importance are the skills necessary for the specific position. 
Each student needs a certain depth of knowledge in all areas of the Commons, with specific training and knowledge required for their area of responsibility. No student is hired with all of the skills, but they are taught and learn quickly through training sessions and assigned tasks. "Training must keep pace with technology changes and system upgrades. Adequate training can involve a great deal of time and money, which are often in short supply in busy, under funded academic libraries” (MacWhinnie, 2003, p.244). To maintain technology currency for the students and also for the full-time employees, weekly training meetings provide information and experience on software programs and on other important topics.

Following is a description of each group and the hiring requisites and training procedures.

Multimedia/computer consultants. The responsibilities of multimedia/computer consultants are substantial. They provide support to patrons who need assistance in creating or editing multimedia projects (video, audio, web site, etc.). They also have the responsibility to troubleshoot computer issues for patrons who come into the Commons. They need to be able to help patrons, whose knowledge and experience range from the novice to the expert, with a variety of software packages. Consultants are hired with a good knowledge of both Macintosh and Windows platforms. In addition, video, sound and graphic creation and editing; web site creation and management; Microsoft Office suite; image scanning and manipulation; OCR scanning; desktop image; printing; wired and wireless networking and printing; and basic knowledge of library research are all part of the skill set.

In the weekly training sessions the multimedia/computer consultants are taught by each other (peer-to-peer training) about different software programs available to patrons on the Commons computers. Each student is assigned a software program to learn and then teach to the group. In this way, each program is learned well by one student and that student becomes a resource for the rest of the group. The most frequently asked questions about computers in the Commons are reviewed and students are prepared to answer them. Customer service skills are also reviewed and enhanced as well as how to conduct a reference interview.

Reference desk assistants. The reference desk assistant's primary responsibilities include assisting patrons to understand the research process, to locate research materials, to find information about the Library and campus. Reference assistants need to be skilled in reference negotiation and possess a sound understanding of general research principles; how to navigate the Library's Web site, article databases, and library catalog; knowledge of the physical library; and knowledge of whom to refer patrons who need additional subject specific help. They also need knowledge of the most common computer support questions, general information about multimedia capabilities, and a basic understanding of library instruction to be able to TA for library instruction classes when needed. Secondary responsibilities include being assigned various projects, such as creating brief catalog records, short training videos, and scanning. 
Meetings for this group consist of training in various databases, reference interview skills, reference desk resources, library information, and any specialized training necessary to complete assigned projects. This group also supports and staffs the Information desk in the library, hence basic knowledge of the campus activities and how to find that information is required. Training is usually accompanied by an assignment that is to be completed by the staff and students. Some training sessions are developed and done by students. This peer-to-peer training, as previously mentioned, allows for one student to become a resource for the others on specific topics. These students also regularly work alongside non-student personnel and receive less structured but valuable shoulder-to-shoulder training from these more experienced individuals.

Full-time staff and faculty. Full-time faculty and staff traditionally have been more knowledgeable in the area of library and information research. They are required to have an in depth knowledge of their area of interest or specialty. In the General Reference area, into which the information commons was integrated, that specialty is general in nature. In addition to the library research and library information skills, a basic knowledge of the other areas of the Commons support is also necessary. Some full-time personnel initially resisted the notion of becoming more familiar with the more technological aspects of the Commons but, through experience, they realize the necessity of such knowledge.

The full-time faculty and staff are trained in much the same way as the students. Given that technology is such a large part of any information commons, full-time personnel have the same responsibility as the students to learn the technology necessary to help all patrons. Many times, the students teach training classes attended by full-time personnel. This is particularly true when it comes to training on new technologies where, in many instances, the students are more knowledgeable than the full-time personnel.

\section{The promise of the future}

"The only constant is change" is an apt statement for the information commons. Technology, students, curricula, and individual needs change so quickly it is hard to keep up with them. Significant change has occurred in just the first eighteen months of BYU's information commons and the pace of change may well accelerate. Librarians must use this change advantageously for patrons whether that means using new information content tools to find information more quickly; learning new types of project or productivity software; producing and delivering new training materials either in enhanced traditional or in previously untried formats; or something else.

\section{Expansion}

It is possible that the physical space of the main commons will grow but in the meantime the concept of a commons is branching out to other parts of the library. Collaborative stations have been installed in the Periodicals, Science, Management/Economics/Government Information and Social Science/Education areas of the Library becoming, in the words of the investigation report, satellite Commons. 
The multimedia computers have been increased in number by two and moved into an adjacent room accessible from the information commons. Ten more individual and twenty more collaboration stations will soon be installed in the Commons. These will provide more resources to the students on campus. However, due to the increased number of computers increasing the number of computer/multimedia assistants may also be necessary.

\section{Adapting to academics}

There is little doubt that the trend in higher education is moving toward more group work for projects. Due to this change, the information commons is expected to continue on the same path toward providing more and better facilities for groups, including an evolving support structure. It may mean that the areas maintain similar layout and functionality as currently instituted or something better as circumstances change.

In addition, like the changes that have already taken place in the first eighteen months with the merger of computer assistants and multimedia assistants, information commons workers are expected to become more competent in answering the wide variety of questions that come their way. This ability to serve patrons regardless of their needs will become more important, especially as those needs become more specialized. Due to the extensive nature of the knowledge needed to support the multimedia area, further training will be necessary for the computer/multimedia assistants in the software used in the information commons. It will also be necessary to train the workers who staff the General Reference desk in more computer related support.

\section{Evaluation and assessment}

As a part of the further development of the information commons an evaluation and assessment program will be developed and implemented. This program will provide both quantitative and qualitative feedback that will help improve the services offered.

It is anticipated that the evaluation project will involve the Instructional Psychology and Technology (IP\&T) program of the university. It is hoped that, with the assistance of the IP\&T program, surveys and other evaluation tools can be implemented to provide helpful feedback in developing and providing new and better services.

\section{Training}

Although training meetings are currently held weekly for Commons personnel, the training program needs further development to re-orient the focus from catering to current or immediate needs to preparing for future needs of the information commons. To provide better service that this kind of advanced preparation will make possible, a more sophisticated training program will be developed. The program will further refine and formalize one-on-one, shoulder-to-shoulder, shadow and cross training, as well as training delivered through regular meetings. 


\section{Campus partners}

In addition to the Publication Lab and the Writing fellows, space has been designated for other potential campus partners such as the Writing Center, Reading Center, Math Lab, Tutoring Services, and Multicultural Student Services. The information commons is becoming a central hub of intellectual activity on campus where students can find many different types of academic services.

\section{Other considerations}

Collaboration stations are designed for group study but are used by individuals as much, if not more, as they are by groups. Consideration has been given to limiting these stations to group use only; possibly during certain times of the day or during certain periods of the semester while not limiting the use of other Commons resources.

Statistics are currently being taken in an effort to discover how often groups are using the information commons, with and without computers. These statistics will be used to help determine what, if anything should be done to encourage more group use of the collaboration stations. This is consistent with the desire to let users of the Commons drive changes. Should it turn out that individual use is inhibiting group use of collaborative stations; one possible remedial approach would be to increase and improve the marketing of these workstations as group facilities to both students and faculty. Technological solutions permitting only group logins might also be investigated.

Use of print reference collections has been declining while use of internet sources is increasing. Thomes (2004) reported that reference librarians have been relying more on the internet for answering reference questions. This has also been the trend at Brigham Young University. Due to this decreased use of the reference collection, the print reference collection may need to be reduced even more. Any reduction in the physical collection would need to be counterbalanced by continued access to these same materials in other ways. The advantage to further reduction of the physical reference collection would be to provide more collaboration and partnership space in the information commons. Since this is the way that academic course work is going, it seems natural for the Commons to go in this direction also. 


\section{Conclusion}

The information commons at Brigham Young University has been a grand success during its first 18 months of operation. This is shown by the constant buzz of activity in the Commons. Every day BYU students reap the benefits resulting from this initiative. From the start of the investigation team to the inauguration of the Commons, one year elapsed. It was a year filled with effort by many stakeholders directed toward making the information commons what it was on opening day. Not all of the familiar components investigated exist in BYU's Commons but what does exist is firmly grounded in the vision and mission of the Lee Library (Harold B. Lee Library, 2005) that the University Librarian informally shortened to "Help Students Learn. Help Teachers Teach. Help Researchers Succeed” (emphasis added).

Support for student learning includes the physical space and resources of the information commons complemented by a dedicated full-time and student staff whose roles are reconfigured as conditions demand and who receive regular training. Students can get help from basic word processing questions to advanced multimedia creation while also receiving the help with researching and retrieving information that has been the traditional hallmark of an academic library.

BYU's information commons will continue to adapt as higher education practice at the University continues to change. Furniture to facilitate collaboration is already being installed in reference areas outside the main information commons and it is likely that more will be installed in the future. This will allow more groups to be accommodated and, at the same time, make it more convenient for those groups to use specialized subject resources. Harder to predict than these changes are those changes that Commons staff will need to make. Because change seems the only constant in an information commons, all who are employed in the Commons must be adaptable and willing to embrace change. Change in information resources and access, academic needs, technological capabilities, and physical spaces and turnover in staff will make inevitable the continued retraining, taking on of new roles, and dropping of previous roles. All in all, the Commons will continue to be an exciting place to study and work!

\section{Note}

1. For example see Bradley, F. 2004, Enabling The Information Commons, available at: http://conferences.alia.org.au/alia2004/pdfs/bradley.f.paper.pdf 


\section{References}

Allmang, N., Liu, R. and Sanders, S. (2006), Building anIinformation Commons at the National Institute of Standards and Technology Library: A Case Study, available at: http://libres.curtin.edu.au/libres15n1/Allmang_Liu_2005_01_31.htm (accessed 5 January) .

Beagle, D. 1999, "Conceptualizing an information commons", The Journal of Academic Librarianship, Vol. 25 No. 2, pp. 82-9, available at: http://vnweb.hwwilsonweb.com/hww/ (accessed 12 December 2005).

Brigham Young University (2005), Aims of a BYU Education, available at: http://unicomm.byu.edu/about/aims (accessed 30 September).

Cowgill, A., Beam, J. and Wess, L. (2001), "Implementing an Information Commons in a university library", Journal of Academic Librarianship, Vol. 27 No. 6, p. 432.

Crockett, C., McDaniel, S. and Remy, M. (2002), "Integrating services in the Information Commons: toward a holistic library and computing environment", Library Administration and Management, Vol. 16 No. 4, pp. 181-6.

Dewey, B.I. (2002), "University of Tennessee's collaborative digital media spaces", $A R L$ Bimonthly Report, Vol. 222, available at: www.arl.org/newsltr/222/collabtenn.html (accessed 30 September 2005).

Harold B. Lee Library (2005), Mission Statements, available at: www.lib.byu.edu/missions.html (accessed 6 January 2006).

Harold B. Lee Library (2003a), Charge to the Information Commons Project Team.

Harold B. Lee Library (2003b), Proposal to Begin Implementation of an Information Commons in the Harold B. Lee Library.

Harold B. Lee Library (2001), Moving Toward the Future: Strategies for the Harold B. Lee Library: 2002-2007.

Kusack, J.M. (2002), "Fostering collaborative learning and group work in libraries", Library Administration and Management, Vol. 16 No. 2, pp. 79-82.

MacWhinnie, L.A. (2003), "The information commons: the academic library of the future", Portal : Libraries and the Academy, Vol. 3 No. 2, p. 241.

Rader, H.B. (1999), "Information literacy in the reference environment: preparing for the future", The Reference Librarian, Vol. 31 no. 66, pp. 213-21.

Thomes, C.L. (2004), The Effect of Online Reference Sources on the Collection and Use of Print Reference Sources, University of North Carolina at Chapel Hill, Chapel Hill, NC. 
Webster's II New College Dictionary, (1995), Webster's II New College Dictionary, Houghton Mifflin Company, Boston, MA.

Wilson, L.A. (2002), "Collaborate or die: designing library space", ARL Bimonthly Report, Vol. 222, available at: www.arl.org/newsltr/222/collabwash.html (accessed 30 September 2005). 
Appendix

In the following table is a comparison of the components of the General Reference/Information Commons area before and after the Information Commons implementation.

\begin{tabular}{|c|c|}
\hline Resources before implementation & Resources following implementation \\
\hline $\begin{array}{l}2 \text { 8-person group study rooms } \\
\text { - Whiteboard } \\
\text { - } 1 \text { network port to connect laptop } \\
\\
\text { to campus network }\end{array}$ & $\begin{array}{l}\text { 2 8-person technology-enhanced group } \\
\text { study rooms } \\
\text { - Whiteboard } \\
0 \quad 1 \text { regular } \\
0 \quad 1 \text { Polyvision Impulse LTX } \\
\text { Multimedia Whiteboard } \\
\text { - Ceiling-mounted projector } \\
\text { - Fixed computer workstation } \\
\text { - Extra ports for laptop } \\
\text { connections to campus network }\end{array}$ \\
\hline $\begin{array}{l}28 \text { 4-chair study tables } \\
\text { • } 26 \text { with network port and } 4 \\
\text { electrical outlets } \\
\end{array}$ & $\begin{array}{l}22 \text { 4-chair study tables each with } \\
\text { • } 16 \text { have network port and } 4 \\
\text { electrical outlets }\end{array}$ \\
\hline $\begin{array}{l}38 \text { individual study carrels } \\
\qquad \quad 2 \text { double-sided } \\
\end{array}$ & 13 individual study carrels \\
\hline $\begin{array}{l}56 \text { computer workstations } \\
\text { - All for individual use } \\
\text { - } 28 \text { required login } \\
0 \quad \text { All included productivity } \\
\text { software } \\
0 \quad 2 \text { on adjustable desks for } \\
\text { disabled patrons } \\
\text { - } 28 \text { required no login } \\
0 \quad \text { Provided internet access only } \\
0 \quad 4 \text { on a walk-up table for brief } \\
\text { searches }\end{array}$ & 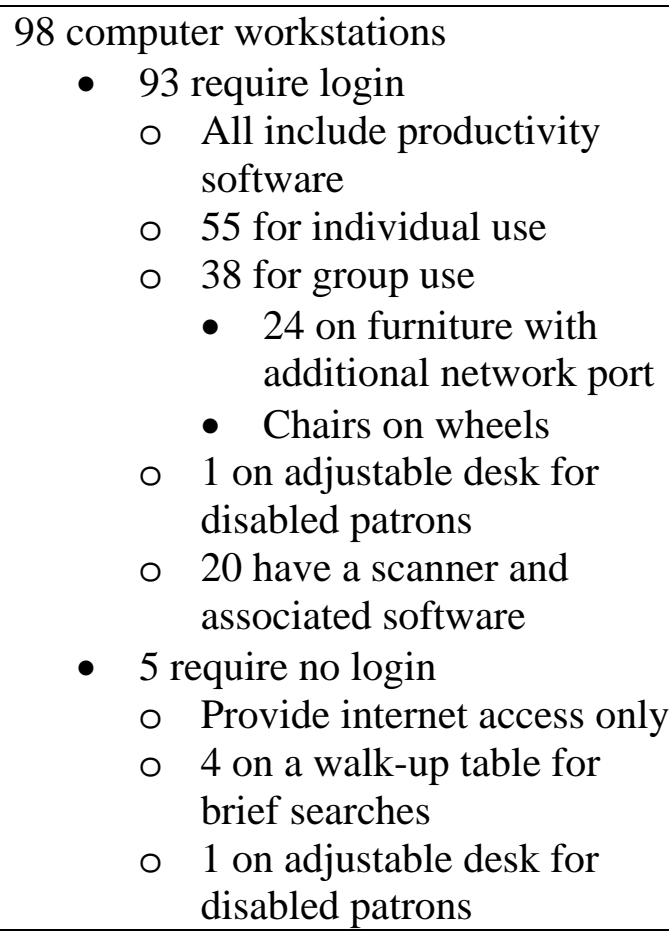 \\
\hline $\begin{array}{l}3 \text { printers on shared print control station } \\
\text { - } 2 \text { Black and white } \\
\text { - } 1 \text { color }\end{array}$ & $\begin{array}{l}\text { 4 printers on shared print control } \\
\text { station } \\
\text { - } 3 \text { Black and white } \\
\text { - } 1 \text { color }\end{array}$ \\
\hline 2 single-sheet copy machines & 2 copy machines \\
\hline
\end{tabular}




\begin{tabular}{|c|c|}
\hline & $\begin{array}{l}\text { - } 1 \text { Single sheet } \\
\text { - } 1 \text { With document feed }\end{array}$ \\
\hline \multirow[t]{4}{*}{$\begin{aligned} & \text { Print reference collection } \\
& \text { - } 5 \text { index tables } \\
& \text { - } 136 \text { 4-shelf double-faced } \\
& \text { shelving units } \\
& \text { - } \text { At approximately } 90 \% \text { capacity }\end{aligned}$} & $\begin{array}{l}\text { Print reference collection } \\
\text { - } 24 \text { 4-shelf double-faced } \\
\text { shelving units } \\
\text { - } \quad \text { At approximately } 40 \% \text { capacity }\end{array}$ \\
\hline & $\begin{array}{l}6 \text { High-end computer workstations for } \\
\text { multimedia creation/editing } \\
\text { - } 4 \text { Macintosh } \\
\text { - } 2 \text { PC } \\
\text { - Associated software } \\
\text { - Associated TV monitors, video } \\
\quad \text { and/or audio decks }\end{array}$ \\
\hline & Wireless capability \\
\hline & $\begin{array}{l}\text { Equipment for checkout } \\
\text { - } 2 \text { Digital video cameras } \\
\text { - } 1 \text { Digital still camera } \\
\text { - } 2 \text { Digital voice recorders } \\
\text { - } \quad \text { Peripheral equipment (e.g. } \\
\\
\text { tripods, wireless mics, etc.) }\end{array}$ \\
\hline \multirow{4}{*}{$\begin{array}{l}1 \text { 60-drawer card-catalog unit containing } \\
2 \text { specialized card indexes } \\
2 \text { 8-drawer microfiche cabinets and an } \\
\text { accompanying reader }\end{array}$} & \\
\hline & \\
\hline & 50 extra stools or chairs on wheels \\
\hline & 8 Lounge-type chairs \\
\hline
\end{tabular}

